\title{
Democratisation of Educational Sciences (Pedagogy) in the Context of the Shift in Political Power of Latvia
}

\author{
Zanda Rubene and Iveta Ozola
}

\begin{abstract}
The purpose of this study is to analyse how political and social changes in society have influenced transformations in the academic discipline of pedagogy in Latvia from 1991 to 2004. Research sources are comprised of materials about notable individuals, theses completed, and scientific degrees obtained, and documentation about and archive materials from the doctoral programme in pedagogy at the University of Latvia. Latvian scholars were isolated from the Western academic field of pedagogy for 50 years, so a process of nostrification took place to prove compliance of those theses with current scientific requirements. It was also important to enrich and renew knowledge about current global research to further develop the communication network of Baltic scholars, as well as to join the networks of European and global researchers. Additionally, it was necessary to change the existing empiric tradition, based on a natural sciences paradigm that applied mostly quantitative research methods. Since 2003, pedagogy has developed according to social sciences methodology and is now defined as a social science. New textbooks had to be translated and developed and pedagogy curricula had to be re-created. It is clear that specific political circumstances influenced the development of pedagogy sciences in Latvia and caused interrupted continuity. Changes in the paradigm since 1991 have not taken place under the "natural" influence of research but due to political events.
\end{abstract}

Keywords: Pedagogy science, interrupted development, democratisation of education

\section{Introduction}

The development of pedagogy as an academic discipline in Latvia is a vivid example of how transformations in the academic sector represent political and social changes in society.

We can discuss the development of pedagogy as an academic discipline starting from 1919 when the University of Latvia was founded. ${ }^{1}$ Today, this

I. Ozola, I. Ķestere, 'Pedagoǵijas kā zinātnes genēze Eiropā (18. gadsimts-20. gadsimta 20.-30. gadi): historiogrāfiskais aspekts' [Geneses of pedagogy as a scientific discipline in Europe $\left(18^{\text {th }}\right.$ century - 1920s-30s)], in A. Krūze, I. Kestere (eds.), Pedagogóijas vēsture. 15 jautājumi [History of Education. 15 questions], Rìga, RaKa, 2010, pp. 78-105; A. Zigmunde, I. Ķestere, 'Latvijas Universitātes Pedagoğijas nodaḷas pirmsākumi, studiju process, mācībspēki un studenti (1919-1944)' [Origins, study process, faculty and students of the Pedagogy Department of the University of Latvia (1919-1944)], in A. Krūze, I. Ķestere (eds.), Pedagogijas vēsture. 15 jautājumi [History of Education. 15 questions], Rìga, RaKa, 2010, pp. 176-203. 
institution is the only classical-type university in the world, providing studies and research potential in all classical and modern fundamental sciences in the Latvian language, ${ }^{2}$ including educational sciences. The genesis of pedagogy as an academic discipline in this study is explained based on the example of the University of Latvia. Sources used in this study include:

1) Information from Post-graduates and PhD graduates at the University of Latvia (1945-2004) $)^{3}$ and Theses developed and completed at the University of Latvia (1996-2004);

2) Doctoral programme of pedagogy, University of Latvia documentation and archive materials;

3) University of Latvia Museum of Pedagogy collection;

4) Špona and Čehlova's Research in pedagogy, ${ }^{5}$ which provides reviews of theses in pedagogy completed at the University of Latvia from 1993 to 2003.

For analysis of the pedagogy/educational science ${ }^{6}$ status quo and prospective analysis we use dimensions developed by Hofstetter and Schneuwly: ${ }^{7}$ institutional, socialisation, methodological, and communicative. ${ }^{8}$

Using the University of Latvia as a case study, we reveal how the abovementioned dimensions were implemented in educational sciences during the turbulent times of change from dictatorship to democracy.

2 H. Strods (ed.), Latvijas Valsts Universitätes vēsture. 1940-1990 [History of the State University of Latvia. 1940-1990], Rīga, Latvijas Universitātes žurnāla 'Latvijas Vēsture’ fonds, 1999.

3 V. Medne (ed.), Latvijas Universitātes aspiranti un doktoranti. I. daļa. Aspirantūras un doktorantūras personāliju, aizstāvēto disertāciju un iegūto zinātnisko grādu apkopojums (1945-2005) [Postgraduates and PhD graduates in the University of Latvia. Part I. Collection of the biographies of post-graduates and $\mathrm{PhD}$ graduates, theses completed and scientific degrees obtained (1945-2005)], Rīga, LU Akadēmiskais apgāds, 2009.

4 D. Paukšēna, I. Rampāne (eds.), Latvijas Universitātē izstrādātās vai aizstāvētās disertācijas (1996-2005) [Theses developed or defended in the University of Latvia (1996-2005)], Riga, LU Akadēmiskais apgāds, 2008.

5 A. Špona, Z. Čehlova, Pètniecība pedagoógijā [Research in pedagogy], Rīga, RaKa, 2004.

6 During the shift of the scientific paradigm and the trans-disciplinary in the 1990s, scholars actively discussed the essence and research subject of two sciences - 'Pedagogy' and 'Educational sciences'. In this article 'Pedagogy science' and 'Educational science' are used as synonyms. See Z. Rubene, 'Pedagog̣ijas zinātne pēc Latvijas neatkarības atjaunošanas' [Pedagogy science after restoration of independence], in A. Krūze (ed.), Laikmets un personība [Era and personality], vol. 15, Rìga, RaKa, 2015, pp. 105-134.

7 Other researchers of the genesis of scientific fields spoke about similar indicators, for example: R. Stichweh, 'Wissenschaftliche Disziplinen: Bedingungen ihrer Stabilität im 19. und 20. Jahrhundert', in J. Schriewer, E. Keiner, Ch. Charle (Hrsg.), Sozialer Raum und akademische Kulturen. Studien zur europäischen Hochschul- und Wissenschaftsgeschichte im 19. und 20. Jahrhundert, Frankfurt am Main, Berlin, Bern, New York, Paris, Wien, Verlag Peter Lang GmbH, 1993, S. 241; K.-P. Horn, 'Disziplingeschichte,' in G. Mertens, U. Frost, W. Böhm, V. Ladenthin (Hrsg.), Handbuch der Erziehungswissenschaft. Band I. Grundlagen - Allgemeine Erziehungswissenschaft, Paderborn, München, Wien, Zürich, Ferdinand Schöningh, 2008, S. 6.

8 R. Hofstetter, B. Schneuwly, Zur Geschichte der Erziehungswissenschaften in der Schweiz. Vom Ende des 19. bis zur Mitte des 20. Jahrhunderts, Bern, hep verlag ag, 2011, S. 20-21. 


\section{Characteristics of the dimensions of pedagogy as a scientific field}

We understand the term 'scientific field' as both the research process (creation of new knowledge) and the result - generalised knowledge in a system about the respective area of reality. As mentioned before, creation and development of a scientific field is characterised by four dimensions: institutional, socialisation, methodological, and communicative. ${ }^{9}$

The institutional dimension, consisting of chairs and professorships in higher education institutions and research institutes and laboratories, enables professionalisation of research and ensures creation and transfer of new knowledge. Institutions provide existence of a scientific field as a self-reproducing system. In addition, institutions develop a research community in the field. It is precisely the activities of these communities that promote further development of the discipline, and institutions secure the existence of sciences as socially communicative systems.

The communicative dimension, or the network of scientific communication (specialised press and book series, research societies and associations, congresses, and other academic events), ensures exchange of views within a research community and existence of a scientific discipline as a transnational communication system. The communicative process in science is formed by development and processing of knowledge, as well as testing and criticism.

The methodological dimension creates scientific knowledge through continuous development and renewal of theoretical models and concepts, data collection and analysis methods, thus ensuring the existence of science as a self-evolving system.

The socialisation dimension ensures preparation of a young generation of researchers and self-reproduction of the field. ${ }^{10}$

Based on these dimensions, we discuss the formation of pedagogy as an independent science in Europe starting from the second half of the $18^{\text {th }}$ century when the first departments of pedagogy/education were founded. ${ }^{11}$ In Latvia, pedagogy sciences were created only in 1919 when the Department of Pedagogy was added to the Faculty of Philology and Philosophy in the newly founded

\footnotetext{
${ }^{9}$ For more about the development of pedagogy as a science and dimensions characterising scientific fields see I. Ozola, 'Pedagog̣ijas zinātnes genenēze Latvijā no 20. gadsimta 20. gadiem lìdz 60. gadu sākumam' [Genesis of pedagogy science in Latvia from the 1920s to the 1960s], PhD diss., University of Latvia, 2013.

${ }^{10}$ R. Hofstetter, B. Schneuwly, Zur Geschichte der Erziehungswissenschaften in der Schweiz. Vom Ende des 19. bis zur Mitte des 20. Jahrhunderts, Bern hep, der Bildungsverlag, 2011, S. 20-21; R. Hofstetter, B. Schneuwly, 'Einleitung. Entstehung und Entwicklung der Erziehungswissenschaft. Herausforderungen und aktuelle Fragen,' in R. Hofstetter, B. Schneuwly, Erziehungswissenschaft(en) 19.-20. Jahrhundert: Zwischen Profession und Disziplin, Bern, Peter Lang Verlag, 2002, S. 39.

${ }^{11}$ The first Department of Pedagogy in German territory was developed at Halle University. See K.-P. Horn, Erziehungswissenschaft in Deutschland im 20. Jahrhundert. Zur Entwicklung der sozialen und fachlichen Struktur der Disziplin von der Erstinstitutionalisierung bis zur Expansion, Bad Heilbrunn/Obb., Verlag Julius Klinkhardt, 2003, S. 13.
} 
University of Latvia and the first professors were appointed. ${ }^{12}$ Achieving university status can be regarded as the main precondition for formation of a scientific discipline, and analysis of the development of the pedagogy in Latvia after 1991 highlights the significance of the University of Latvia in the development and maintenance of this academic discipline. We should not underestimate the contribution of other institutions in research and development of pedagogy, but the University of Latvia's doctoral programme could be considered the main centre of academic pedagogy.

Development processes that took place in all dimensions should be analysed in correlation. When speaking about preparation of a new generation of researchers, the socialisation dimension cannot be isolated from the institutional dimension. Thus, we explain the development of pedagogy science in Latvia in detail, analysing processes and changes that took place from 1991 to 2004 in the institutional, communicative, and methodological dimension.

\section{Context: pedagogy science in Latvia during the interwar period and under Soviet rule}

Development of pedagogy sciences took place during changes of ruling powers. Therefore, to analyse the period from 1991 to 2004, it is necessary to provide a short insight into the background of pedagogy as an academic discipline.

During the 1920s-30s, pedagogy in Latvia developed through German humanist traditions (geisteswissenschaftliche Pädagogik). ${ }^{13} \mathrm{~A}$ small but active number of Latvian scholars worked at the University of Latvia. They developed the study programmes and taught pedagogy, pedagogical psychology, and the history of pedagogy, preparing a new generation of scholars. The knowledge of these professors was widely published in books, articles, and in the pedagogical press. Latvian pedagogues upgraded their knowledge in European universities (especially Germany), and they travelled abroad for business and exchange of expertise. All preconditions for the formation of pedagogy as an independent scientific discipline were provided, and it developed in compliance with the current academic trends of Europe.

During the interwar period, Latvian pedagogy developed in humanist traditions based on idealism, a significantly different approach than

${ }^{12}$ A. Krūze, 'Pedagogiijas un psihologijas katedra' [Pedagogy and Psychology Department], in A. Varslavāns (ed.), Latvijas Universitāte 75 [University of Latvia. The $75^{\text {th }}$ Anniversary], Rigga, Latvijas Universitāte, 1994, p. 337.

${ }^{13}$ More about the formation and development of the pedagogy science in Latvia during the interwar period see I. Ozola, 'Pedagoǵijas zinātnes genēze Latvijā no 20. gadsimta 20. gadiem līdz 60. gadu sākumam' [Genesis of pedagogy science in Latvia from the 1920s to the 1960s], PhD diss., University of Latvia, 2013; A. Zigmunde, I. Ķestere, 'Latvijas Universitātes Pedagogijas nodalıa zem divām okupācijām' [Department of Pedagogy of the University of Latvia under two occupations], in A. Vỉksna (ed.), Zinātņu vēsture un muzejniecība. Latvijas Universitātes Raksti [History of sciences and museology. Scientific papers. University of Latvia], vol. 780, Rīga, Latvijas Universitāte, 2012, pp. 313-325. 
the materialist, scientific worldview in the Soviet Union. Thus, after the incorporation of Latvia into the Soviet Union in 1940, Latvian interwar period achievements were regarded as inappropriate for Soviet ideology. Humanist-based pedagogy was replaced with Marxist-Leninist pedagogy based on social class theory. Trivialised Marxism was imported from the Soviet Union in ready-made forms, namely, professors educated in the Soviet Union were appointed to the State University of Latvia. ${ }^{14}$ They implemented pedagogy programmes and textbooks prepared in the Soviet Union, and Latvian mass media published leading Soviet scholar theories translated from Russian into Latvian. ${ }^{15}$

Post-World War II pedagogy applied social sciences research methods observation, experiments, interviews, a.o. ${ }^{16}$ - forming an empiric social science. Research was performed using only the imported Marxist-Leninist paradigm, excluding the latest scientific trends of Europe and the world. All scientific dimensions of pedagogy again were only fully developed in the late 1950s/ early 1960s when the first generation of researchers were raised in MarxistLeninism pedagogy traditions at the State University of Latvia. ${ }^{17} \mathrm{New}$ Marxist pedagogy researchers began to develop their own pedagogy course programmes and published research results in press and article collections, but the first textbook written by a Latvian author was published only in $1987 .{ }^{18}$ Therefore, development of pedagogy science under the Soviets can be only characterised as relatively comprehensive: we can speak more of the contribution of Latvian scholars in the development of institutional, communicative and socialisation dimensions of pedagogy science.

\section{Interrupted continuity of pedagogy science}

Within the context of the shift in the scientific paradigm, we can conclude that development of pedagogy sciences did not take place according to the Thomas Kuhn scientific revolution theory. The Kuhn theory states that scientific discipline develops as a self-evolving system 1) by acquiring new

${ }^{14}$ State University of Latvia - name of the university during both Soviet occupation periods 1940-1941 and 1944-1991.

${ }^{15}$ For development of pedagogy science in Latvia under Soviet rule see also A. Krūze, 'Development of Pedagogy as a Science in the Baltic Republics under Soviet Rule', in I. Kestere, A. Krūze (eds.), History of Pedagogy and Educational Sciences in the Baltic Countries from 1940 to 1990: an Overview, Rìga, RaKa, 2013, pp. 230-234; A. Krūze, I. Ozola, 'Pedagogy as Science in Latvia,' in I. Kestere, A. Krūze (eds.), History of Pedagogy and Educational Sciences in the Baltic Countries from 1940 to 1990: an Overview, Riga, RaKa, 2013, pp. 234-242.

${ }^{16}$ I. A. Kairov (ed.), Pedagogika [Pedagogy], Moskva, Gosudarstvennoje učebno-pedagogičeskoje izdatẹ̦stvo miņisterstva prosveščenija RSFSR, 1956, pp. 17-18.

${ }_{17}$ Until 1960s Latvian researchers of pedagogy studied in post-graduate programmes of other universities in the Soviet republics and defended their theses mostly in Moscow and Leningrad, also Vilnius.

$18 \mathrm{~J}$. Anspaks, Ievads marksistiski l̦eniniskajā pedagoğijā [Introduction to Marxist-Leninist pedagogy], Rīga, P. Stučkas Latvijas Valsts universitāte, 1987. 
knowledge and opinions during the scientific process that can't be explained in the frame of the dominant paradigm or 2) when problems emerge that can't be solved within the existing paradigm. When these two preconditions apply, the crisis can be resolved only with a change of paradigm. When this new paradigm gains an increasing number of supporters in the scientific community, scientific revolution is created resulting in a change of paradigm. ${ }^{19}$ Within the specific political circumstances of Latvia, development of pedagogy science did not fit into the scientific revolution theory as it was not connected with the development of science itself - creation of new methods, concepts, paradigms - but was imposed by a change in the ruling order.

The first paradigm shift happened when the pedagogy science developed during 1920s-30s was replaced by imported and trivialised Marxist pedagogy in the 1940s. A similar situation could be observed after regaining independence in 1991 with regards to a change of paradigm. Although the change in political power in 1991 was part of democratisation processes, the paradigm change (for the second time) did not take place under "natural" influences of scientific concepts but due to political events. During the 1990s, Marxist-Leninist pedagogy concepts were abandoned as they were no longer suitable to the new state order and the new perceptions of raising the young generation. Regardless of whether democracy shifted to totalitarianism or vice versa, the same trends could be observed in the development of pedagogy sciences in Latvia, i.e. direct influence of politics in the academic field. Consequently, the restoration of independence in Latvia resulted in the interruption of the natural evolutionary path and development of pedagogy science.

\section{Analysis of pedagogy science development on the institutional dimension}

Academic restoration procedures in the University of Latvia began before regaining independence in 1991 in both content and institutional perspectives: in October 1989, the Scientific Communism Chair was transformed into the Political Science Department; in June 1990, the Faculty of Theology was restored; and in June 1991, the Civil Defence Department was liquidated. ${ }^{20}$ Mandatory military training was also removed from curricula.

Changes in the university educational systems of all three Baltic countries were introduced after 1988, most notably in the renewal of democratic principles and cancellation of previously existing contextual and methodical limitations

\footnotetext{
19 T. Kuhn, Struktura naučnih revoḷucij [Structure of scientific revolutions], Moskva, AST, 2009.

${ }^{20}$ A. Varslavāns (ed.), Latvijas Universitāte 75 [University of Latvia. The $75^{\text {th }}$ Anniversary], Rìga, Latvijas Universitāte, 1994; H. Strods (ed.), Latvijas Valsts Universitātes vēsture. 1940-1990 [History of the Latvian State University. 1940-1990], Rìga, Latvijas Universitātes žurnāla 'Latvijas Vēsture’ fonds, 1999.
} 
and especially in the social sciences and humanities. Transition from the Soviet scientific degree structure ${ }^{21}$ to the Western model took place. ${ }^{22}$

The Pedagogy and Psychology Department established under Soviet rule continued to function. In 1992, a Master's programme was initiated providing studies in general and social pedagogy. The Department was the basis for doctorate studies in pedagogy: in 1992, Board of Doctoral Studies in Pedagogy was added to the department and it managed doctoral study programmes and completion of theses.

In 1996, the Department of Pedagogy and Psychology became the University of Latvia Institute of Pedagogy and Psychology and operated as such until 2003. In 2004, the Institute was merged with the Faculty of Pedagogy and Psychology, establishing the Department of Pedagogy that continued the work of the former institute. ${ }^{23}$

Development of pedagogy and other social sciences and humanities during the post-Soviet period revealed specific problems caused by 50 years of isolation from the academic experience of the world. As during the Soviet era, when pedagogy science needed to adjust to the ruling communist ideology, after Latvia regained independence, its researchers frequently experienced cautious and biased attitudes from scholars of the "hard" sciences and from society in general.

In the beginning of 1990s researchers of social sciences and humanities were subjected to nostrification process demanding repeated evidence of the compliance of their theses with the current scientific requirements. On 1 October 1991, regulations 'On allocation of academic degrees' were adopted and a Board of Doctoral Studies in Pedagogy of the University of Latvia was established, which performed the nostrification or repeated recognition of the USSR academic degrees. Until June 1999 - 123 pedagogy scholars were nostrified. ${ }^{24}$

Emotionally, nostrification was a very difficult process - especially for researchers of the older generation. Therefore, few of them even decided not

${ }^{21}$ Under Soviet rule, a two-level scientific degrees system existed in Latvia - Candidate of Sciences and Doctor of Sciences. Since 1993, only the doctoral degree (PhD) remains. See V. Medne (ed.), Latvijas Universitātes aspiranti un doktoranti. I. daḷa. Aspirantūras un doktorantūras personāliju, aizstāvēto disertāciju un iegūto zinātnisko grädu apkopojums (1945-2005) [Post-graduate and doctoral students of the University of Latvia. Part I. Compilation of the post-graduate and doctorate students, completed theses and acquired academic degrees], Rìga, LU Akadēmiskais apgāds, 2009.

22 OECD centrs sadarbībai ar nedalibbvalstīm [OECD Centre for Cooperation with Non-Member States], Nacionālo izglìtības politiku analīze. Latvija [Analysis of national educational policies. Latvia], Rīga, Profesionālās izglìīibas attīstības programmas aǵentūra, 2002.

${ }^{23}$ A. Krūze, 'Pedagog̣ijas nodą̧a' [Department of Pedagogy], in A. Krūze, LU Pedagoǵijas, psihologíijas un mākslas fakultäte zinātnei un izglìtībai [Faculty of Pedagogy, Psychology and Arts of the University of Latvia for science and education], Rìga, LU Akadēmiskais apgāds, 2013, pp. 89-121.

${ }^{24}$ Pedagogy Museum Collection of the University of Latvia. 
to take part in this procedure, therefore denying themselves the opportunity to participate in the scientific community of independent Latvia.

Sources about the number of $\mathrm{PhD}$ thesis completed in pedagogy science from 1992 to 2003 are contradictory. Especially about the period when nostrification took place, as well as the period when the transition from the two level to one level Doctoral degrees system occurred (until 1998). As compilers of the review acknowledge, it was not easy to obtain information about theses completed during the first half of 1990 s as in this period strict regulations about handing over of the manuscript and summary to scientific libraries were lacking, as well as the requirement to notify about the presentation of theses in mass media was not always precisely followed. ${ }^{25}$

On the basis of the report about pedagogical studies in Latvia at the turn of the $21^{\text {st }}$ century in the monograph 'Research in Pedagogy', we can conclude that from 1993 to 2003, 91 scientists of pedagogy completed their Doctoral theses, including 18 doctor habilitus theses. ${ }^{26}$

In 1999, the Cabinet of Ministers adopted 'Regulations on the Procedure and Criteria of the Doctoral Thesis.'27 These amendments to the law determined the formation of Qualification Committee in the frame of the Latvian Academy of Sciences. Duties of the Committee were related to evaluation of the quality of submitted theses. Also, a requirement was set that theses should be internationally discussed in conferences and publications.

Creation of the Qualification Committee explains the large number of theses completed in the first half of 1999 in comparison to 2000. There were 15 theses completed in pedagogy in 1999. However, in 2000, when the Qualification Committee had already started the evaluation process, only one (!) thesis was presented.

After the collapse of the Soviet Union, pedagogy researchers in Latvia also encountered the lack of study materials based on modern global academic achievements and democratic values. University of Latvia professors developed new curricula of pedagogy, constantly improving their knowledge. Textbooks used during the Soviet era "vanished" from reading lists, including the knowledge accumulated (excepting books by Soviet authors Iljina and Babanskis that were used after $1991^{28}$ ).

${ }^{25}$ V. Medne (ed.), Latvijas Universitātes aspiranti un doktoranti. I. daļa. Aspirantūras un doktorantūras personāliju, aizstāvēto disertāciju un iegūto zinātnisko grādu apkopojums (1945-2005) [Postgraduate and doctorate students of the University of Latvia. Part I. Compilation of the postgraduate and doctorate students, completed theses and acquired academic degrees], Riga, LU Akadēmiskais apgāds, 2009; D. Paukšēna, I. Rampāne (eds.), Latvijas Universitātē izstrādātās vai aizstāvêttās disertācijas (1996-2005) [Theses developed or defended in the University of Latvia (1996-2005)], Rīga, LU Akadēmiskais apgāds, 2008.

${ }^{26}$ A. Špona, Z. Čehlova, Pētniecība pedagoğijä [Research in pedagogy], Rīga, RaKa, 2004.

${ }^{27}$ D. Paukšēna, I. Rampāne (eds.), Latvijas Universitātē izstrādātās vai aizstāvētās disertācijas (1996-2005) [Theses developed or defended in the University of Latvia (1996-2005)], Riga, LU Akadēmiskais apgāds, 2008.

${ }^{28}$ O. Zìds (ed.), Vispārējā pedagoğija. Darba programma akadēmiskajām studijām pedagoǵijā un psihologijia a [General pedagogy. Academic study programme in pedagogy and psychology], Rìga, 
Lists of textbooks in 1990s curricula of pedagogy indicate that equal value was given to modern Western authors as to Soviet authors and Latvian literature of the 1920s-30s. This demonstrates that students did not receive integral current pedagogical knowledge and shows also the confusion of professors.

It was necessary to renew the range of available textbooks in libraries in a short period of time. Introduction of the Internet in Latvia in 1992 helped to solve this problem, but much can be attributed to the development of international mobility of university professors and students. During the transition period, it was common to receive textbooks as gifts from Latvians in Western exile, ${ }^{29}$ as well as from new cooperation partners in the West. Required literature was translated, en masse, into Latvian with the support of various international foundations (such as the Soros Foundation). Also, Latvian pedagogy researchers were actively involved in the development of their own Latvian textbooks in pedagogy and books related to various pedagogical theories and practice.

\section{Pedagogy science development on the methodological dimension}

Isolation from current global research had created a situation in which post-Soviet researchers were frequently not well-acquainted with the most important global theories. It created the necessity for the academic staff to rapidly acquire their discipline anew.

Post-Soviet academic staff during the 1990s had insufficient foreign language skills, which encumbered their inclusion into the international scientific community. Soviet people from Latvia, who had resided behind the Iron curtain, knew primarily only Latvian and Russian. Therefore, "success stories" in the early 1990s were related not as much with professional qualities as with foreign language skills - good knowledge of English, German, or French was a springboard for good career development. During the 1990s, research in Latvia was characterised by expressed focus towards the West and isolation from Russian culture and scientific traditions that, once again, basically created a decidedly one-sided approach to pedagogy. ${ }^{30}$

During the first years of independence, social sciences and humanities regained the focus of the interwar period: development was oriented towards

Latvijas Universitāte, 1991; M. Pḷaveniece, I. Ķestere, 'Autorprogramma kursam 'Pedagogiija" [Author's programme for the course 'Pedagogy'], manuscript, around 1991; M. Plaveniece, I. Kestere, 'Darba programma kursam 'Pedagogija' [Programme for the course 'Pedagogy'], manuscript, after 1991, Pedagogy Museum Collection of the University of Latvia.

${ }^{29}$ J. Stradinšs, 'Ceḷavārdi II Pasaules latviešu zinātnieku kongresam' [Farewell words during the II World Congress of Latvian Scientists], in II Pasaules latviešu zinātnieku kongress. Tēžu kräjums [II World Congress of Latvian Scientists. Compilation of conference abstracts], Latvijas Zinātnuu akadēmija, Rìga, 2001, p. 35.

${ }^{30}$ Z. Rubene, 'Geisteswissenschaften und akademische Bildung in Lettland', in P. GutjahrLöser, D. Schulz, H.W. Wollersheim (Hrgs.), Theodor-Litt-Jahrbuch 2010/7, Leipzig, Leipziger Universitätsverlag, 2010, S. 57-73. 
maintaining national values, preserving national identity, care for the social and national course of the state, and towards implementation of global and European intellectual values in the future. ${ }^{31}$

In pedagogy in the 1990s, the empiric or experimental tradition developed during Soviet period continued to operate but creation of an international scientific network and the popularity of interwar period pedagogical thought resulted in a transformation of methodology during the latter 1990s. Two opposite trends could be observed: 1) a return to the understanding of pedagogy as the applied philosophy that dominated during the 1920s-1930s, and 2) the continuation and fostering of the positivism tradition in pedagogy. It should be noted that both these directions did not match the actual perception of pedagogy sciences in the world during the 1990s and did not promote inclusion of Latvia into the European academic community. This paradoxical situation attests to the previously mentioned concept that, although Latvia gained independence in 1991 and the state structure changed from totalitarian to democratic, the natural development and continuity of pedagogy science was interrupted again.

Until 1997, theses completed in pedagogy covered the same two areas as they did during Soviet period: 1) pedagogy theory and history and 2) pedagogy of branches (teaching methods). In 1998, pedagogy disciplines became more versatile: 6 doctoral theses were completed in various pedagogy areas -5 in general pedagogy, 1 - preschool pedagogy and 1 in university pedagogy. ${ }^{32}$ In 1999, the first doctoral thesis in school and adult education were presented.

A small number of pedagogy theses completed during this period represent the humanitarian paradigm in regards to cognitive orientation, for example, Teachers - writers in the pedagogy theory and practice in Latvia from 1900 to 1940 $(2002)^{33}$ and Theory development of religion pedagogy (2002). ${ }^{34}$ These studies were developed using traditional methods of humanities, mostly hermeneutic text interpretation. But, theses in pedagogy still applied quantitative research methods using empiric pedagogy traditions based on a natural sciences paradigm.

The first doctoral theses in social pedagogy was presented in 2003 (shortly before Latvia joined the European Union), demonstrating a new cycle in the development of pedagogy science in Latvia. ${ }^{35}$ In 2003, the doctoral thesis

${ }^{31}$ J. Ekmanis, 'Augstskola, zinātne, valstiskums - viens veselums' [University, science, statehood one entirety], in H. Grīnberga (ed.), Virzìtājspēks. Rakstu krājums par augstāko izglìt̄̄bu Latvijā [Driving force. Compilation of articles about higher education in Latvia], Rìga, Izglitíbas un zinātnes ministrija, 2007, pp. 137-151.

32 A. Špona, Z. Čehlova, Pētniecỉba pedagoǵijä [Research in pedagogy], Rīga, RaKa, 2004.

${ }^{33}$ B. Kalı̣e, 'Skolotāji - rakstnieki pedagogijas teorijai un praksei Latvijā no 1900. lỉdz 1940. gadam' [Teachers - writers in pedagogy theory and practice in Latvia from 1900 to 1940], $\mathrm{PhD}$ diss., University of Latvia, 2002.

${ }^{34}$ S. L. Remese, 'Religíijas pedagogijas teoriju attīstība' [Theory development of religion pedagogy], PhD diss., University of Latvia, 2002.

${ }^{35}$ M. Dirba, 'Latvijas identitāte: pedagogiskais aspekts' [Identity of Latvia: pedagogical aspect], PhD diss., University of Latvia, 2003. 
Improvement of the learning skills of young people during the Danish language learning process ${ }^{36}$ applied qualitative research methods. The doctoral thesis Research of the critical thinking process of young people during the study process in university, ${ }^{37}$ presented in January 2004, was developed according to social sciences methodology and pedagogy was defined as a social science in this study.

\section{Pedagogy science development on the communicative dimension}

In discussion of the communicative dimension of pedagogy science, we should analyse both that contribution of the pedagogy researchers in the development of the communication network in Latvia, as well as the inclusion process of the University of Latvia pedagogy scholars in the network of European and global researchers.

As mentioned earlier, pedagogy science encountered "methodological confusion" after Latvia regained independence: Soviet period theories were abandoned as not suitable for the new situation and were rapidly substituted with the ideas of Latvian authors from the interwar period. This definitely did not promote the development of science.

It was also important to introduce practitioners of education with the latest pedagogy science concepts that could help to implement educational ideals suitable to a democratic society. The magazine Skolotājs (Teacher) became one of these communication channels: its target audience were pedagoguespractitioners, and it was published in Latvian from 1996 to $2011 .^{38}$ Starting with the second issue of the magazine, University of Latvia pedagogy researchers regularly published theoretical and methodological articles, thus introducing a broad part of the educational society to their research results and current global issues in pedagogy science. Several University of Latvia pedagogy researchers sat on the editorial board of the magazine. We should emphasise the column 'A word to the scientist', created as a platform for discussion of scholars with educational practitioners. University of Latvia academics and doctoral students of pedagogy wrote for this column. ${ }^{39}$

${ }^{36}$ E. Maslo, 'Jauniešu mācīšanās spēju pilnveide dāņu valodas mācību procesā' [Improvement of the learning skills of young people during the Danish language learning process], $\mathrm{PhD}$ diss., University of Latvia, 2003.

${ }^{37}$ Z. Rubene, 'Jauniešu kritiskās domāšanas izpēte studiju procesā universitātēe [Research of the critical thinking process of young people during the study process in university], $\mathrm{PhD}$ diss., University of Latvia, 2004.

${ }^{38}$ A. Šmite, 'Pedagogiskais žurnāls 'Skolotājs' Latvijas izglìtībai (1996-2011)' [Pedagogic magazine 'Teacher' for the Latvian education (1996-2011)], in A. Krūze (ed.), Laikmets un personìba [Era and personality], vol.15, Riga, RaKa, 2015, p. 462.

${ }^{39}$ For example: A. Krūze, 'Atceroties Jāni Gresti' [Remembering Jānis Greste], Skolotājs [Teacher], no. 2, 1997, pp. 78-81; A. Krūze, 'Starptautiskie semināri - pieredzes bagātināšanas forma' [International workshops - a form of widening your horizons], Skolotäjs [Teacher], no. 2, 2000, pp. 13-15; A. Špona, 'Pirmsskolas audzināšanas teorija un prakse' [Preschool learning theory 
To reclaim its position in the European cultural and scientific space, promotion of international cooperation was one of the academic community's most urgent tasks. Researchers were confronted with the necessity to gain recognition in the scientific area, which could be achieved by strengthening international cooperation networks and publishing their studies outside Latvia. Targeted internationalisation of scientific activities began, which meant development of the international cooperation network. If during the Soviet period, international contacts were formed mostly with other Soviet colleagues and Warsaw block member states, then after Latvia regained independence, special attention was paid to strengthening cooperation with researchers from Western Europe and the USA. ${ }^{40}$

Scholars from the global exile Latvian community actively promoted recognition of Latvian researchers and fostered international cooperation. In 2001, the Second World Congress of Latvian Researchers took place in Riga (the first Congress took place in 1991 before the restoration of independence) in which over 800 delegates from Latvia and 200 Latvians from abroad participated. The aim of the Congress was to promote the return of global-level research in Latvian universities and cooperation with foreign educational and science centres. Direct contacts with exile Latvian researchers were recognised as the drivers of development of new scientific thinking. ${ }^{41}$ Pedagogy science was also represented at this congress - 27 pedagogy researchers took part with 22 presentations. ${ }^{42}$

During the 1990s, international cooperation among pedagogy researchers from the Baltic states was also strengthened. In 1999, a symposium in Riga

and practice], Skolotājs [Teacher], no. 2, 2002, pp. 10-13; A. Špona, 'Audzināšana kā sabiedrības kvalitātes pilnveidošanās prioritāte' [Upbringing as the society quality improvement priority], Skolotājs [Teacher], no. 2, 2002, pp. 29-31; I. Žogla, 'Skolas pedagogija' [School Pedagogy], Skolotājs [Teacher], no. 5, 1997, pp. 8-10; I. Žogla, 'Mūsdienu mācību teorijas' [Modern scholastic theories], Skolotājs [Teacher], no. 4, 2001, pp. 4-8; I. Maslo, 'Mācību metodes izglìitības iestādë' [Learning methods in the educational establishment], Skolotājs [Teacher], no. 6, 1998, pp. 5-7; E. Černova, 'Pirmklasnieka gatavība mācību darbībai' [Readiness of the first grader for the learning process], Skolotājs [Teacher], no. 4, 2000, pp. 12-14; I. Ķestere, 'Sociālās pedagogiijas jēdziens pirmās brīvvalsts laikä [Social pedagogy concept during the first free state period], Skolotājs [Teacher], no. 5, 2001, pp. 103-105; I. Margeviča, 'Bilingvālās izglìitības pieredze Eiropā' [Bilingual education experience in Europe], Skolotājs [Teacher], no. 6, 2001, pp. 44-46; I. Šümane, 'Mācību vides veidošanās' [The development of the study environment], Skolotājs [Teacher], no. 6, 2001, pp. 46-48; S. Tübele, 'Kāpēc skolēns nelasa' [Why the student does not read], Skolotājs [Teacher], no. 6, 2001, pp. 49-52; T. Koḳe, 'Mūžizglìtības pedagogiskie pamati' [Pedagogical basis of the lifelong learning], Skolotājs [Teacher], no. 2, 2002, pp. 4-8.

${ }^{40}$ I. Dedze, Z. Rubene, 'Universities in Latvia - from the Soviet to European Higher Education Area,' Foro de Education, vol. 14, no. 21, 2016, pp. 13-38.

${ }^{41}$ J. Stradiņš, 'Ceḷavārdi II Pasaules latviešu zinātnieku kongresam' [Farewell words during the II World Congress of Latvian Scientists], in II Pasaules latviešu zinātnieku kongress. Tēžu kräjums [II World Congress of Latvian Scientists. Compilation of conference abstracts], Rìga, Latvijas Zinātṇu akadēmija, 2001, p. 35.

${ }^{42}$ 'Sekcija 'Pedagog̣ija' [Section 'Pedagogy'], in II Pasaules latviešu zinātnieku kongress. Tēžu krājums [II World Congress of Latvian Scientists. Compilation of conference abstracts], Rìga, Latvijas Zinātṇu akadēmija, 2001, pp. vii-viii. 
gathered pedagogy historians from Estonia, Latvia, and Lithuania: the Baltic Association of Historians of Pedagogy (BAHP) was created, even though it had functioned, unofficially, since the 1970s. In 2000, BAHP was founded as legal entity with divisions in Lithuania and Estonia. ${ }^{43}$

The first international research project was a study initiated by Professor Josef Held of University of Tübingen (Germany) - 'International learning' (Internationales Lernen). In the beginning the project included five countries (Germany, Greece, Latvia, Croatia and Netherlands), but later included another three (Spain, Poland, Switzerland). The project lasted from 1991 to 2007 and provided the opportunity to work in an international team and develop and initiate innovations for the promotion of the integrity of society in Latvia.

Studies on current topics were performed as part of this project; for example, researching social inclusion and isolation problems that was an issue for the young people of Latvia. Alongside research work, meetings with Latvian youth took place. In addition, two international conferences were organised in Riga in 1992 and 1998, and methodology workshops for project participants and other university staff, including Master's and Doctoral programme students were held. Four monographs were published, including Youth Between Integration and Isolation (Jugend zwischen Integration und Ausgrenzung. Ergebnisse eines internationalen Projekts) in 1999.

During the 1990s, cooperation between the University of Latvia and Leipzig University was very important for the development of the international pedagogy science communication network. This cooperation, which has continued for over 20 years, began in 1998 with Professor Dieter Schulz's lecture at the Konrad Adenauer Foundation Political Education Centre in Wendgreben. ${ }^{44}$ In 2002, Leipzig University became the first foreign university to welcome University of Latvia pedagogy doctoral students through the ERASMUS exchange programme. Both universities continue to organise international workshops for pedagogy researchers: initially, Latvian scholars were the recipients of knowledge and experience, but over time, both parties have become equal discussion partners.

University of Latvia pedagogy researchers have also been involved in international scientific associations that promote inclusion in European and global networks. The University of Latvia has been a Member of the Association for Teacher Education in Europe (ATEE) since 1997. The first ATEE conference in Riga took place in 2002. ${ }^{45}$ Organisation of this conference in Latvia can be

43 'Baltic Association of the Historians of Pedagogy'. Available: http://www.baltichistorians.lu.lv/ index.php?id=3 (accessed 23 March 2017).

${ }^{44}$ A. Krūze, 'Leipcigas Universitātes profesors Dīters Šulcs - Latvijas Universitātes Goda doktors kopš 2002. gada' [Leipzig University professor Dieter Schulz - Honorary Doctor of the University of Latvia since 2002], in A. Krūze (ed.), Laikmets un personìba [Era and personality], vol.15, Rìga, RaKa, 2015, pp. 279-294.

45 'Association for Teacher Education in Europe, University of Latvia, Institute of Education and Psychology,' in ATEE Spring University 'Decade of reform: achievements, challenges, problems, Rìga, Izglìtibas solị, 2002. 
regarded as a reference point for the readiness of Latvian scholars to join in discussions with researchers from all over Europe as equal partners.

\section{Conclusion}

Analysing development of pedagogy science in Latvia, we can confirm that from 1991 to 2004, interrupted continuity could be observed in the institutional, communicative, and methodological dimensions. Disregarding whether rule changed from democracy to totalitarianism or vice versa, the natural evolution of the development of pedagogy science was interrupted in Latvia, thus losing the succession of science development.

Nevertheless, pedagogy science in the $21^{\text {st }}$ century is still developing comprehensively: the contribution of the community of Latvian scholars is not only in development of separate dimensions of pedagogy science - institutional, communicative, and socialisation - as it was under Soviet rule, but also in implementation of targeted development in all scientific dimensions. Initially, this development was implemented by returning to the conceptual space of Europe as well as mastering the current practices of higher education of Europe, but later, this occurred through establishment of modern scientific models that comply with the needs of a democratic state and form a sound basis for equal discussion with colleagues around the world. Along with the change of generations, the ideological implications created by the Soviet totalitarian regime are vanishing. 